\title{
Neotrombicula inopinata (Acari: Trombiculidae) - a possible causative agent of trombiculiasis in Europe
}

\author{
Alexandr A Stekolnikov ${ }^{1 *}$, Paula Santibáñez ${ }^{2}$, Ana M Palomar ${ }^{2}$ and José A Oteo²
}

\begin{abstract}
Background: For over a decade, the presence of trombiculid mites in some mountain areas of La Rioja (Northern Spain) and their association with seasonal human dermatitis have been recognized. This work aimed to establish the species identity of the agent causing trombiculiasis in the study area.

Methods: Trombiculid larvae (chigger mites) were collected from vegetation in the Sierra Cebollera Natural Park and in Sierra La Hez during an outbreak of human trombiculiasis in 2010. Three specimens collected from a bird were also examined. Identification was made using morphological and morphometric traits based on the most recent taxonomic sources. A comparison of those mites with specimens of the same species collected throughout Europe was performed by means of cluster analysis with multiscale bootstrap resampling and calculation of approximately unbiased p-values.
\end{abstract}

Results: All collected mites were identified as Neotrombicula inopinata (Oudemans, 1909). Therefore, this species is the most likely causative agent of trombiculiasis in Spain, not Neotrombicula autumnalis (Shaw, 1790), as it was generally assumed. No chigger was identified as $\mathrm{N}$. autumnalis in the study area. Neotrombicula inopinata clearly differs from $\mathrm{N}$. autumnalis in the presence of eight or more setae in the 1st and 2nd rows of dorsal idiosomal setae vs. six setae in N. autumnalis. Comparison of $\mathrm{N}$. inopinata samples from different locations shows significant geographic variability in morphometric traits. Samples from Western and Eastern Europe and the Caucasus formed three separate clusters.

Conclusion: Since the taxonomical basis of many studies concerning N. autumnalis as a causative agent of trombiculiasis is insufficient, it is highly possible that $N$. inopinata may be hiding behind the common name of "harvest bug" in Europe, together with N. autumnalis.

Keywords: Harvest bug, Trombiculiasis, Neotrombicula autumnalis, Neotrombicula inopinata, Spain

\section{Background}

Nowadays, four chigger mite species are proven to attack humans in Europe causing trombiculiasis - Neotrombicula autumnalis (Shaw, 1790), Kepkatrombicula desaleri (Methlagl, 1928), Blankaartia acuscutellaris (Walch, 1922), and Trombicula toldti Winkler, 1953 [1]. The last one is a mite of unclear taxonomic position, which is still known solely from its type locality in Austria [2]. Blankaartia acuscutellaris is associated with reedy margins of water

\footnotetext{
* Correspondence: Alexandr.Stekolnikov@zin.ru

'Zoological Institute, Russian Academy of Sciences, Universitetskaya Embankment 1, St. Petersburg 199034, Russia

Full list of author information is available at the end of the article
}

bodies (rivers, lakes, swamps, etc.). This widespread species principally infests birds inhabiting such biotopes, and humans are occasional hosts [1]. Kepkatrombicula desaleri parasitizes ungulates and has only been recorded on humans by the author who originally described it [3]. Unlike most trombiculids, this species is characterized by the presence of a sucker disk in the apical part of the hypostome that allows it to feed successfully on large hosts [4].

Neotrombicula autumnalis has been reported as the most frequent causative agent of human trombiculiasis in Europe [5-10], and its role as "harvest bug" has been
C Biomed Central (c) 2014 Stekolnikov et al.; licensee BioMed Central Ltd. This is an Open Access article distributed under the terms of the Creative Commons Attribution License (http://creativecommons.org/licenses/by/2.0), which permits unrestricted use, distribution, and reproduction in any medium, provided the original work is properly credited. The Creative Commons Public Domain Dedication waiver (http://creativecommons.org/publicdomain/zero/1.0/) applies to the data made available in this article, unless otherwise stated. 
attributed without sufficient taxonomic criteria [11,12]. To date, the harvest bug's taxonomy remains unclear. Thus, Richards distinguished several forms of this species when designating the neotype of $N$. autumnalis [12]. Later, Kepka raised them to the subspecies level and equated two of them with the previously described taxa, Neotrombicula inopinata (Oudemans, 1909) and Neotrombicula vernalis (Willmann, 1942) [13]. Nowadays, both have been assigned the species rank [14-17]. Therefore, it is highly possible that the common name of "harvest bug" comprises more than one trombiculid species in Europe.

Neotrombicula autumnalis has been found in different locations in northern Spain [18-20]. Thus, cases of human and canine trombiculiasis have been recorded annually in La Rioja (North of Spain) from late summer to midautumn $[21,22]$. Dermatitis associated with chigger bites has repeatedly been a cause of public health concern in La Rioja, and in 2008 a study of trombiculiasis was financially supported by the Regional Government. One of the aims of this project was to correctly identify the chiggers present in this Region, since all cases had been ascribed to $N$. autumnalis despite no proper taxonomic identification ever having been carried out. Trombiculid larvae were collected in areas where the presence of mites and seasonal dermatitis cases in humans had been previously confirmed [21]. The collection of questing chiggers from vegetation allowed us to suggest the possible causative agent of trombiculiasis in the study area.

\section{Methods \\ Collections}

Chigger mites were collected during the scheduled samplings of a three-year study (2008-2010) by members of the Infectious Diseases Department, Center for Biomedical Research of La Rioja. A proportion of the chigger specimens collected on randomly-selected sample days were included in this study. According to the seasonality of human trombiculiasis in La Rioja, field collections were carried out from September to November 2010. Unfed trombiculid larvae ready to seek hosts were collected as follows:

1. The black-plate method, which is commonly used when collecting free trombiculid larvae from the ground, was combined with the flag technique, used to collect ticks on vegetation. Thus, a $20 \times 40 \mathrm{~cm}$ black plastic plate with two strings at opposite corners was dragged over the ground. Chiggers were transferred into tubes containing distilled water with the aid of a brush.

2. By direct capture: chiggers on the upper surface of the leaves or on small dry branches were directly collected into tubes.
Additionally, three chiggers were removed with a swab from an Erithacus rubecula (L.) specimen captured during a bird ringing campaign carried out in the same area by Aranzadi Sciences Society and Abies Environment Resources Inc.

\section{Chigger collection sites}

Three sampling areas in La Rioja (North-West of the Central Iberian System, North of Spain) were chosen according to the proven existence of human and canine trombiculiasis:

1. La Pineda, $42^{\circ} 06^{\prime} 00^{\prime \prime} \mathrm{N}, 2^{\circ} 33^{\prime} 00^{\prime \prime} \mathrm{W}$. It is located in Sierra Cebollera Natural Park, at 1,270-1,330 m above sea level (a.s.l.) (Figure 1). This location belongs to the municipal district of Lumbreras, $2.5 \mathrm{~km}$ away from the nearest village, San Andrés. Collections were made on 14th and 19th September, 4th and 11th November 2010 in a grove of Pinus sylvestris L. with undergrowth of Erica vagans L., Ilex aquifolium L., Prunus spinosa L., Juniperus communis L., and Rubus fruticosus L. Most chiggers were found on Brachypodium sp. at 15-40 cm above the ground (Figure 2) or on defoliated and dried branches of $P$. spinosa and $P$. sylvestris lying on the ground, at a height of 25-50 cm (Figure 3). Collection of chiggers from a bird was carried out in this location on 19th September, 2010.

2. Valdecalvo, $42^{\circ} 07^{\prime} 00^{\prime \prime} \mathrm{N}, 2^{\circ} 31^{\prime} 30^{\prime \prime} \mathrm{W}$. It is located $4 \mathrm{~km}$ away from San Andrés and c. 2-3 km away from the previous location, at 1,400 $\mathrm{m}$ a.s.l. The vegetation has the same characteristics as described above for La Pineda. Sampling was performed on 4th November 2010.

3. Ocón, 42 $17^{\prime} 15^{\prime \prime} \mathrm{N}, 02^{\circ} 14^{\prime} 30^{\prime \prime} \mathrm{W}$. This place is located in the Sierra de La Hez (Leza-Jubera Basin). The collection site is located $2 \mathrm{~km}$ away from Ocón and c. $33 \mathrm{~km}$ away from previous locations, at $1,050 \mathrm{~m}$ a.s.l. Chiggers were collected on 7 th October, 2010 in a Quercus pyrenaica Willd. grove with undergrowth of Cytisus scoparius (L.) Link, Pteridium aquilinum (L.) Kuhn, Brachypodium sp., and Rubus fruticosus.

For morphological comparison, $N$. inopinata samples representing widely separated parts of Europe and preserved as microscopic slides in different depositories were used (Figure 4):

1. Two specimens (Institut Royal des Sciences Naturelles de Belgique, Bruxelles) from Glis glis (L.), Belgium, Torgny, $49^{\circ} 30^{\prime} \mathrm{N}, 5^{\circ} 28^{\prime \prime}$ E, 1955, coll. A Fain.

2. Ten specimens [Zoological Institute RAS (ZIN), St. Petersburg, Russia] from Prunella modularis (L.), 


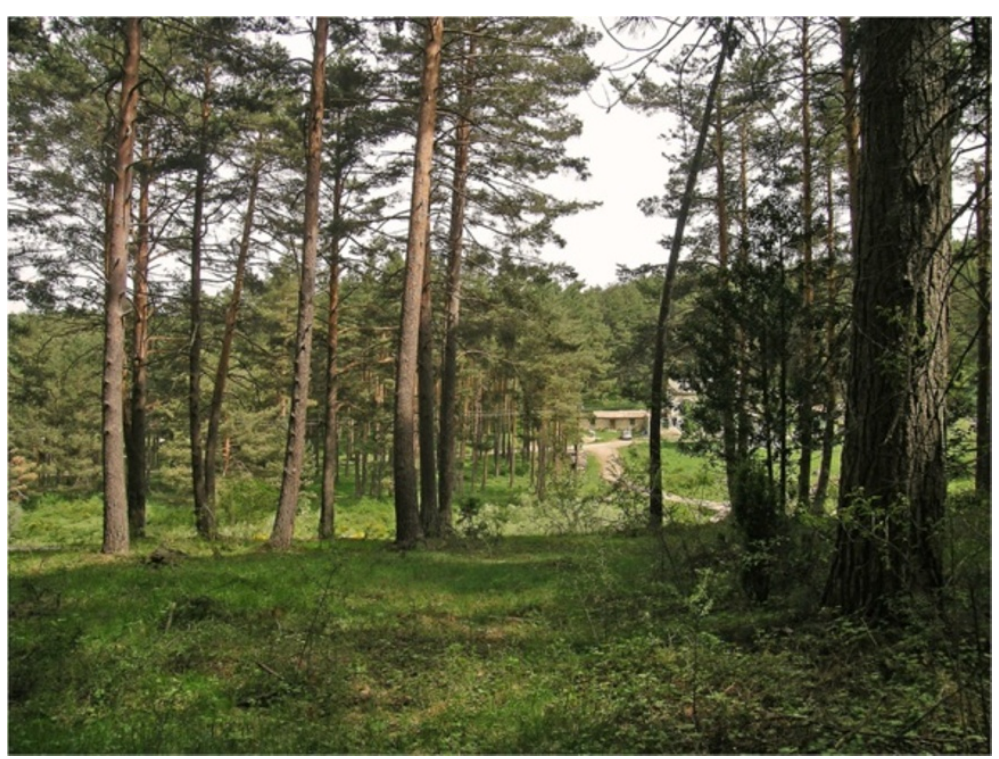

Figure 1 Collection site in La Pineda.

Sylvia atricapilla (L.), and E. rubecula, Czech Republic, Nový Jičin, 493' N, 17²59' E, 31.07-15.08.2005, coll. I Literák [23].

3. Six specimens [Zoological Museum of Moscow University (ZMMU), Moscow, Russia] from Myodes glareolus (Schreber), Ukraine, Transcarpatia, Rakhiv Raion, Kvasivsky Menchul Mt., 48 $10^{\circ} \mathrm{N}, 24^{\circ} 20^{\prime} \mathrm{E}$, 8.09.1959, coll. SO Vysotzkaja, identified as Neotrombicula germanica (Willmann, 1952) [24].

4. Ten specimens (ZMMU) from M. glareolus, Ukraine, Transcarpatia, Rakhiv Raion, coordinates unknown, 5.09.1959, coll. SO Vysotzkaja, identified as N. germanica [24].

5. Nine specimens (ZMMU) from M. glareolus, Bulgaria, Pirin Mts, $41^{\circ} 46^{\prime} \mathrm{N}, 23^{\circ} 24^{\prime} \mathrm{E}$, 21-22.10.1960, coll. L Hristov, identified as N. germanica [25].

6. One specimen (ZMMU) from M. glareolus, Bulgaria, Vitosha Mts, $42^{\circ} 34^{\prime} \mathrm{N}, 23^{\circ} 17^{\prime} \mathrm{E}, 7.11 .1960$, coll. G Markov, identified as N. germanica [25].

7. Ten specimens (ZIN) from Sorex raddei Satunin and Apodemus (Sylvaemus) sp., Russia, Kabardino-Balkaria,

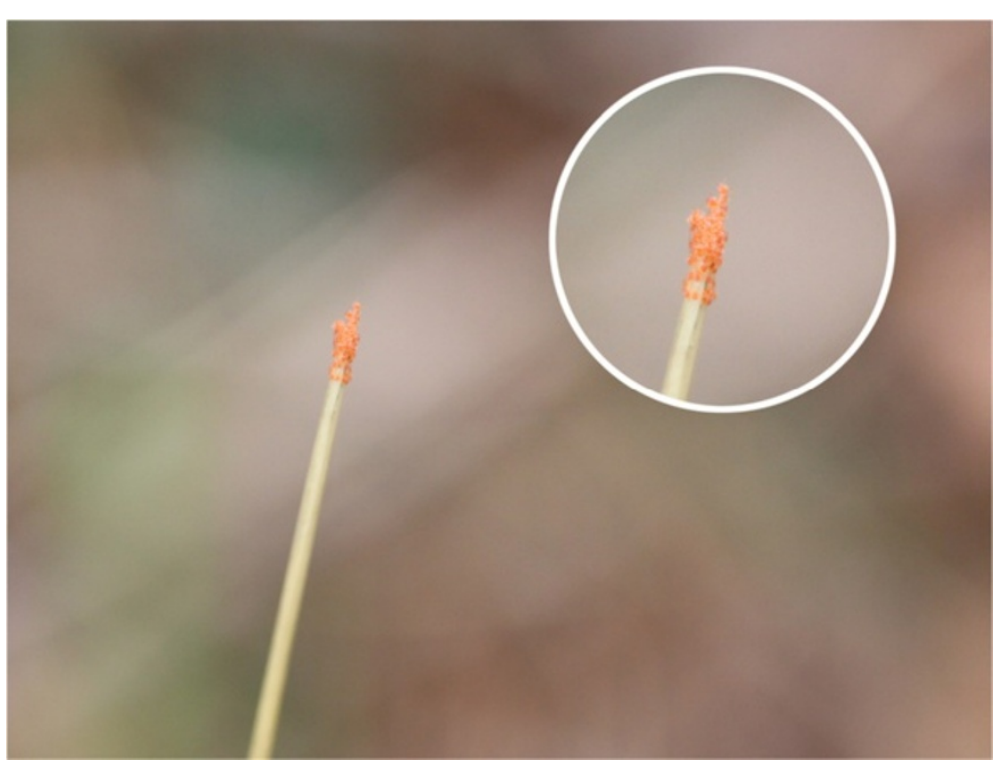

Figure 2 Cluster of unfed chigger mites at the end of a grass stalk, La Pineda. 


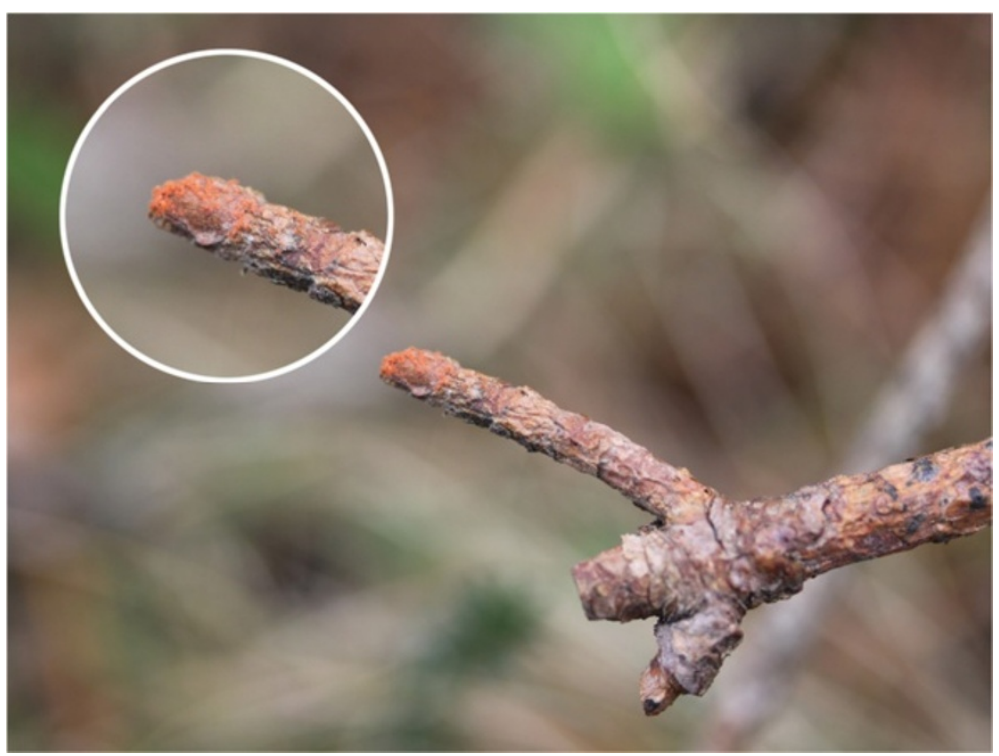

Figure 3 Cluster of unfed chigger mites on a dried branch of Pinus sylvestris, La Pineda.

Nalchik, 4326' 20" N, 43 35'47" E, 24.06.1996, coll. AA Stekolnikov.

8. Seven specimens (ZIN) from Microtus sp., Russia, North Ossetia-Alania, Alagir, $43^{\circ} 02^{\prime} \mathrm{N}, 44^{\circ} 13^{\prime} \mathrm{E}$, 18.04.1976, coll. SN Rybin.

9. Nine specimens (ZIN) from Cricetulus migratorius (Pallas), Apodemus (Sylvaemus) sp., and Chionomys gud (Satunin), Russia, Dagestan, Mazada, 42 $11^{\prime} 40^{\prime \prime}$ N, 46 22' 26" E, 11-12.07.1988, coll. AB Shatrov. 10.One specimen (ZIN) from Apodemus (Sylvaemus) sp., Russia, Dagestan, $6 \mathrm{~km}$ E from Khnov, 41 $21^{\prime}$ $29^{\prime \prime}$ N, 47³1'36" E, 22.06.1988, coll. AB Shatrov.

\section{Preparation and examination}

Specimens from La Rioja selected for this work were fixed in $70 \%$ ethanol; 87 specimens were then mounted on microscopic slides in Faure-Berlese medium under uniform conditions. Clarified preparations were examined under a compound microscope MBI-3 (LOMO plc, St. Petersburg, Russia) with phase contrast optics. Measurements were made with an ocular micrometer and converted to micrometers. Digital photographs of mites were acquired with a Leica DM5000B microscope equipped with a DFC320 digital camera (Leica Microsystems Wetzlar $\mathrm{GmbH})$, using differential interference contrast microscopy. All examined specimens are archived at ZIN (Nos 8250-8336).

\section{Statistical evaluation}

The bootstrapping cluster analysis was used to estimate relative morphometric closeness between $N$. inopinata collected in La Rioja and samples from other regions. The

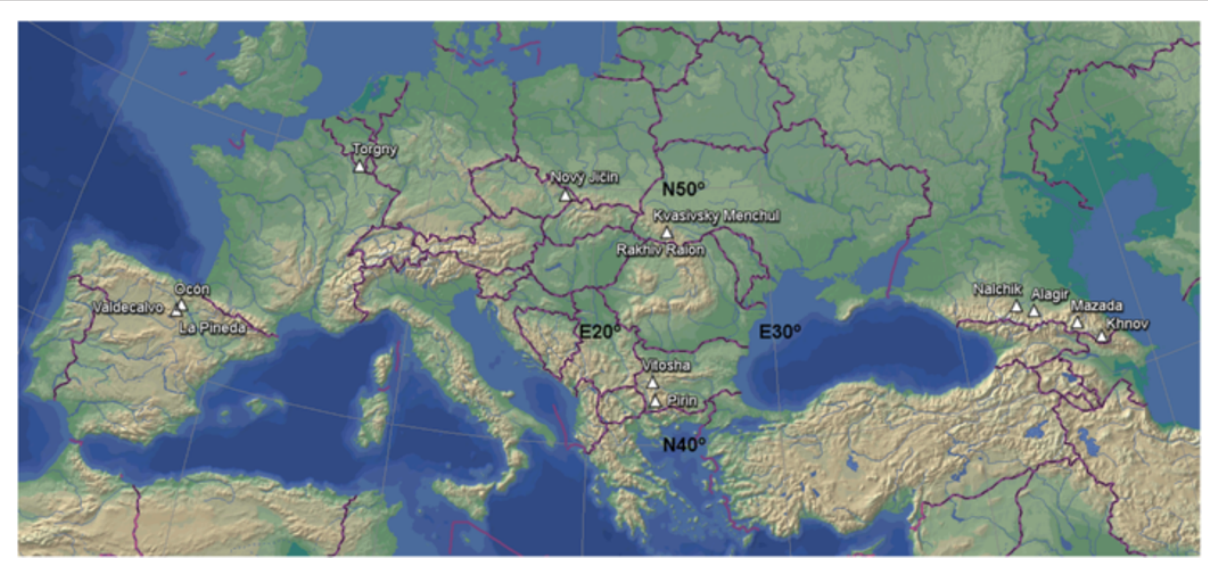

Figure 4 Collection sites for Neotrombicula inopinata. 
analysis was based on the following 17 characters: AW (distance between anterolateral scutal setae), PW (distance between posterolateral scutal setae), SB (distance between sensillary bases), ASB (distance from the level of sensillary bases to extreme anterior margin of scutum), PSB (distance from the level of sensillary bases to extreme posterior margin of scutum), P-PL (distance from the level of posterolateral scutal setae to extreme posterior margin of scutum), AP (distance from anterolateral to posterolateral scutal setae on one side), AM (length of anteromedian seta of scutum), AL (length of anterolateral setae of scutum), PL (length of posterolateral setae of scutum), $\mathrm{H}$ (length of humeral idiosomal setae), pa (length of leg I, including coxa), pm (length of leg II, including coxa), pp (length of leg III, including coxa), DS (number of dorsal idiosomal setae), VS (number of ventral idiosomal setae), and dmt (distance from the base of leg III tarsus to the base of mastitarsala). Leg lengths were divided by 10 in order to equalize the magnitude of their variation with other variables [26].

Specimens with data missing for any variable were excluded from the analysis. The single specimen from Vitosha Mts was found to be an outlier and therefore was excluded. Lastly, the number of OTUs (Operational Taxonomic Units) was 12, and their sizes were as follows: La Pineda 10, Valdecalvo 5, Ocón 9, Torgny 2, Nový Jičin 10, Kvasivsky Menchul 6, Rakhiv Raion 10, Pirin 8, Nalchik 10, Alagir 7, Mazada 5, and Khnov 1. Mean values were calculated for each of them. Then the UPGMA clustering algorithm (Unweighted Pair Group Method with Arithmetic Mean) applied to the matrix of Euclidean distances between 12 OTUs by the above 17 variables was used. The number of bootstrap replications in the analysis was 1000 .

The computations were performed using pvclust module [27] in the " $R$ " software environment ver. 2.14.1 [28]. The package provides AU (approximately unbiased) p-values $[29,30]$ and BP (bootstrap probability) p-values. For a cluster with $\mathrm{AU}$ p-value $>0.95$, the hypothesis that "the cluster does not exist" is rejected with significance level 0.05 and such clusters can be considered as strongly supported by data [31]. We can also conclude, from our experience [26], that $\mathrm{AU}$ p-values slightly lesser than the threshold may also characterize well-delineated clusters.

\section{Results and discussion}

All 87 examined specimens from La Rioja, including 84 collected from vegetation (54 in La Pineda, 15 in Valdecalvo, and 15 in Ocón) and 3 from the bird, were identified as $N$. inopinata (Oudemans, 1909) (Figures 5, 6 and 7). This species was described from Germany (Bremen) and later recorded also from England, France, Austria, Yugoslavia, Bulgaria, Ukraine, Russia (Northern Caucasus) [15], Romania [32], Hungary [33], Slovakia [34], Czech Republic [35], and Poland [36]. Here, we describe for

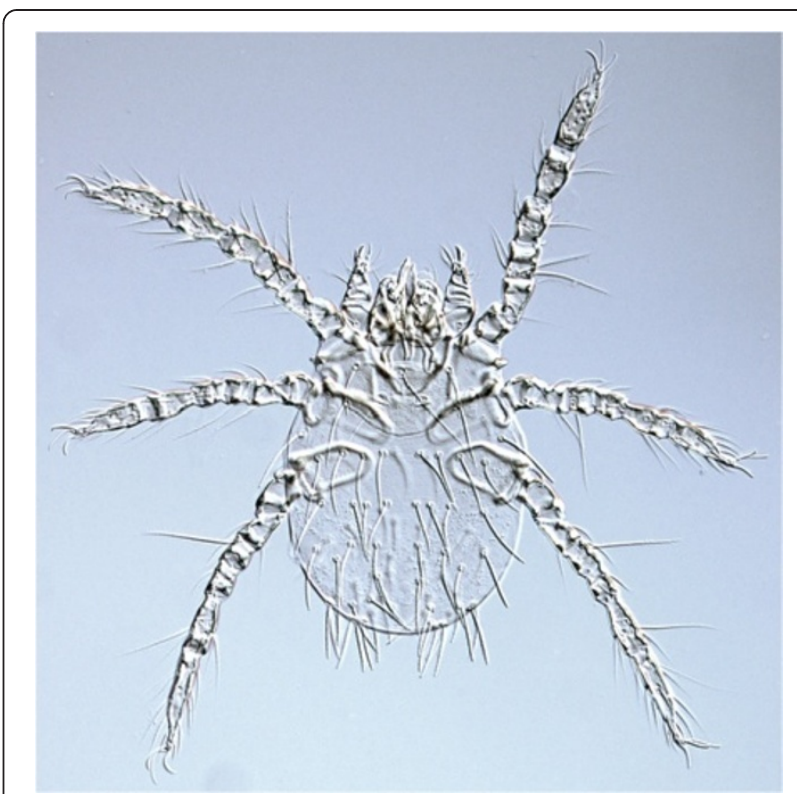

Figure 5 Neotrombicula inopinata, general view.

the first time $N$. inopinata from Spain. The identification was achieved using appropriate descriptions and figures [15]. This species is characterized by the nude galeal seta (situated on the hypostome lobe between the cheliceral blade and the palp on each side), branched setae on palpal

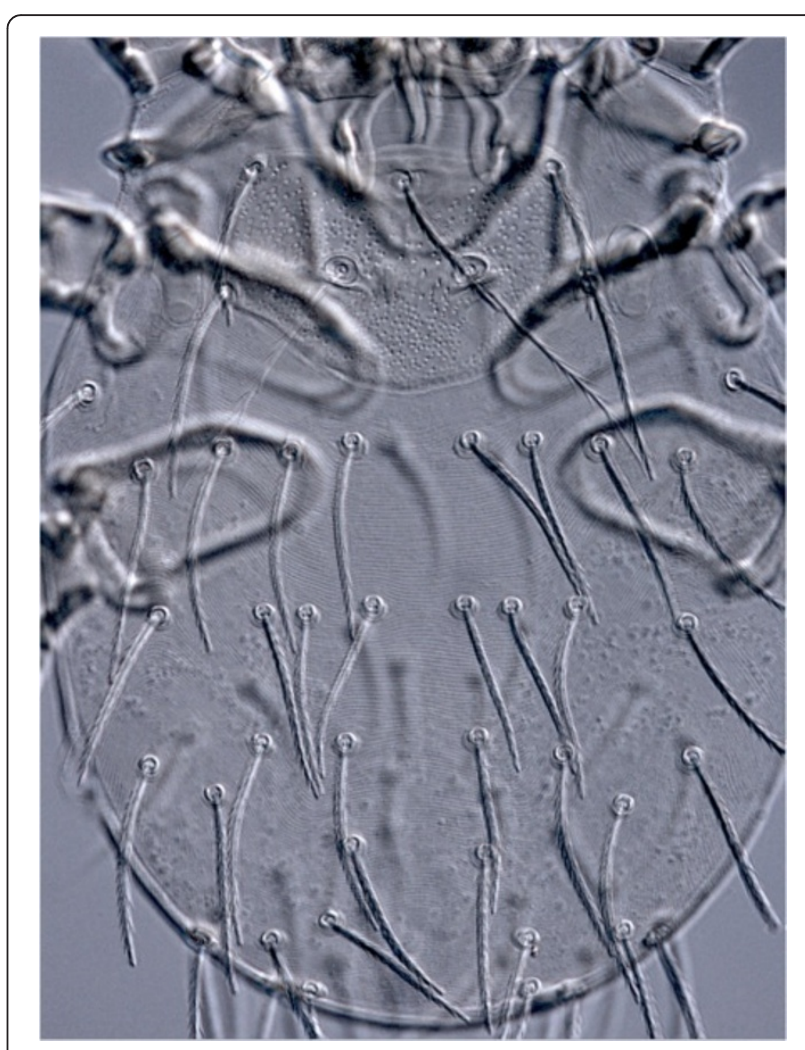

Figure 6 Neotrombicula inopinata, dorsal aspect of idiosoma. 


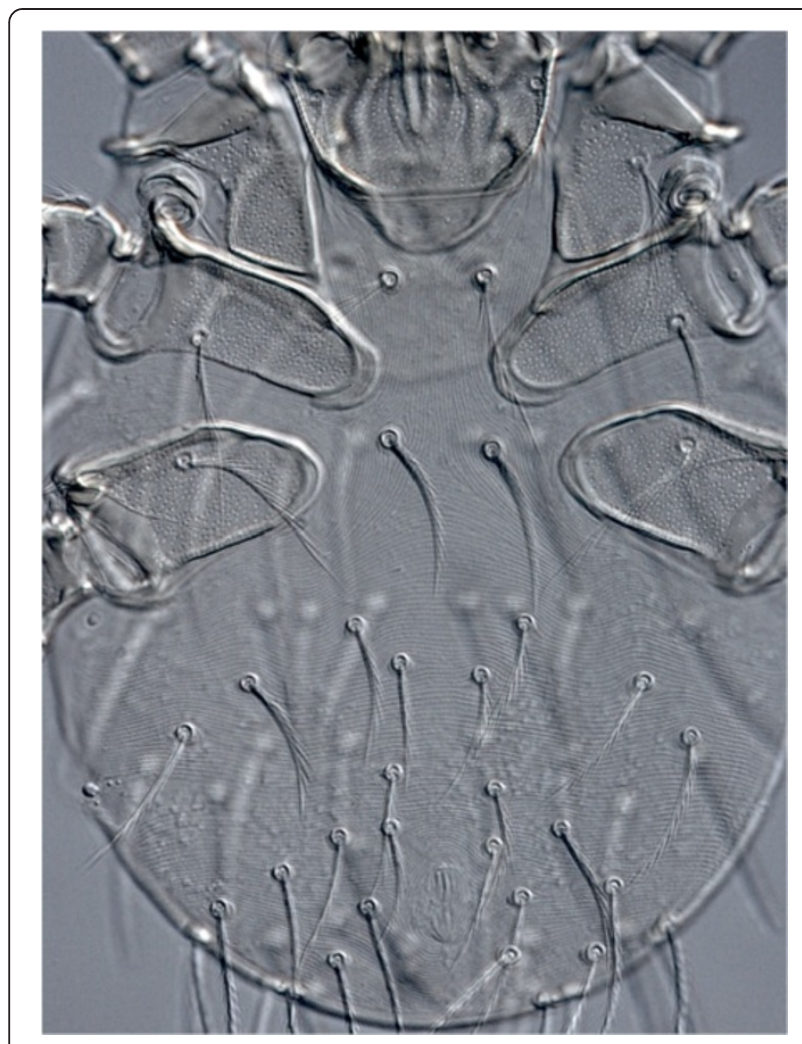

Figure 7 Neotrombicula inopinata, ventral aspect of idiosoma.

femur and genu, nude dorsal and lateral setae on palpal tibia, branched ventral palpal tibial seta, three genualae and one microgenuala I (specialized nude setae on leg genu), presence of a long nude seta on the leg tarsus III (mastitarsala), two humeral setae (most anterior marginal dorsal idiosomal setae) and 36-45 other dorsal idiosomal setae arranged as (6-11)-(8-13)-(6-10)-(2-10)-(2-9)-(0-6), with typical variant 8-8-8(6)-4-6-2 (Figure 6). The characteristic traits of the genus Neotrombicula Hirst, 1925 are available from several sources $[14,17,37]$.

The comparison of the sample from La Rioja with specimens from the other regions (Table 1) showed that the former was distinguished first of all by shorter dmt and, consequently, smaller m-t (ratio dmt/TaIII where TaIII is a length of leg III tarsus), by a lower number of ventral idiosomal (VS) (Figure 7) and therefore all idiosomal setae (NDV = DS + VS), and by shorter anteromedian seta of scutum (AM). That these differences represent intraspecific variation is evident from their comparison with the ranges of variation in other widely distributed Neotrombicula species [38-40]. Moreover, a concordance between morphometric and geographic distances among OTUs can be clearly seen from Figure 8 , where three clusters with significant statistical support (AU p-values > 0.95) correspond to groups of geographically closest samples (three OTUs from Spain, two from Caucasus,
Table 1 Standard measurements of Neotrombicula inopinata

\begin{tabular}{|c|c|c|c|c|}
\hline \multirow[b]{2}{*}{ Variable } & \multicolumn{2}{|c|}{ La Rioja $(n=24)$} & \multicolumn{2}{|c|}{ Other sites $(n=65)$} \\
\hline & Range & Mean & Range & Mean \\
\hline AW & $68-78$ & 73 & $71-82$ & 77 \\
\hline PW & $82-93$ & 88 & 86-104 & 95 \\
\hline SB & $26-33$ & 31 & $31-41$ & 35 \\
\hline ASB & $29-32$ & 31 & $29-38$ & 33 \\
\hline PSB & $27-32$ & 30 & $24-34$ & 31 \\
\hline SD & $56-63$ & 60 & $54-69$ & 64 \\
\hline$P-P L$ & $23-30$ & 26 & $21-32$ & 29 \\
\hline AP & $27-33$ & 30 & $25-36$ & 31 \\
\hline AM & $41-56$ & 45 & $43-65$ & 57 \\
\hline $\mathrm{AL}$ & $38-46$ & 43 & $40-49$ & 45 \\
\hline$P L$ & $52-61$ & 56 & $54-74$ & 62 \\
\hline S & $68-81$ & 75 & $63-101$ & 85 \\
\hline $\mathrm{H}$ & $54-63$ & 57 & $54-77$ & 63 \\
\hline$D_{\min }$ & $38-49$ & 42 & $36-50$ & 44 \\
\hline$D_{\max }$ & $50-58$ & 54 & $50-67$ & 58 \\
\hline$V_{\min }$ & $29-36$ & 33 & $26-38$ & 34 \\
\hline$V_{\max }$ & $41-48$ & 45 & $43-65$ & 52 \\
\hline pa & $310-337$ & 324 & $274-331$ & 300 \\
\hline $\mathrm{pm}$ & $265-295$ & 282 & 248-299 & 270 \\
\hline $\mathrm{pp}$ & $306-335$ & 320 & $277-342$ & 310 \\
\hline Ip & 887-963 & 925 & 808-967 & 880 \\
\hline DS & $36-44$ & 38 & $36-45$ & 40 \\
\hline VS & $22-30$ & 26 & $23-47$ & 36 \\
\hline NDV & $60-72$ & 64 & $66-90$ & 77 \\
\hline Talll & $77-86$ & 82 & $67-85$ & 76 \\
\hline $\mathrm{dmt}$ & $9-15$ & 11 & $11-21$ & 17 \\
\hline$m-t$ & $0.109-0.177$ & 0.139 & $0.138-0.288$ & 0.220 \\
\hline
\end{tabular}

and three from Ukraine plus Bulgaria). It is noteworthy that upper-level grouping of all 12 OTUs, although without the same support, follows the geographical (meridian) sequence of sample sites (Figure 4), creating three large clusters consisting of Western European, Eastern European, and Caucasian samples, respectively.

The fauna of trombiculids in Spain, based on collection of chiggers from small mammals, reptiles and birds included 18 species, according to Kepka [18,41], Varma [42], Pereira-Lorenzo [19], and Imaz et al. [20]. In particular, 10 trombiculid species were recorded on Apodemus sylvaticus (L.) from Navarra, a region bordering La Rioja [20]. The description of $N$. inopinata collected from vegetation in La Rioja has raised to 19 the number of trombiculid species in Spain:

Blankaartia acuscutellaris (Walch, 1922), 


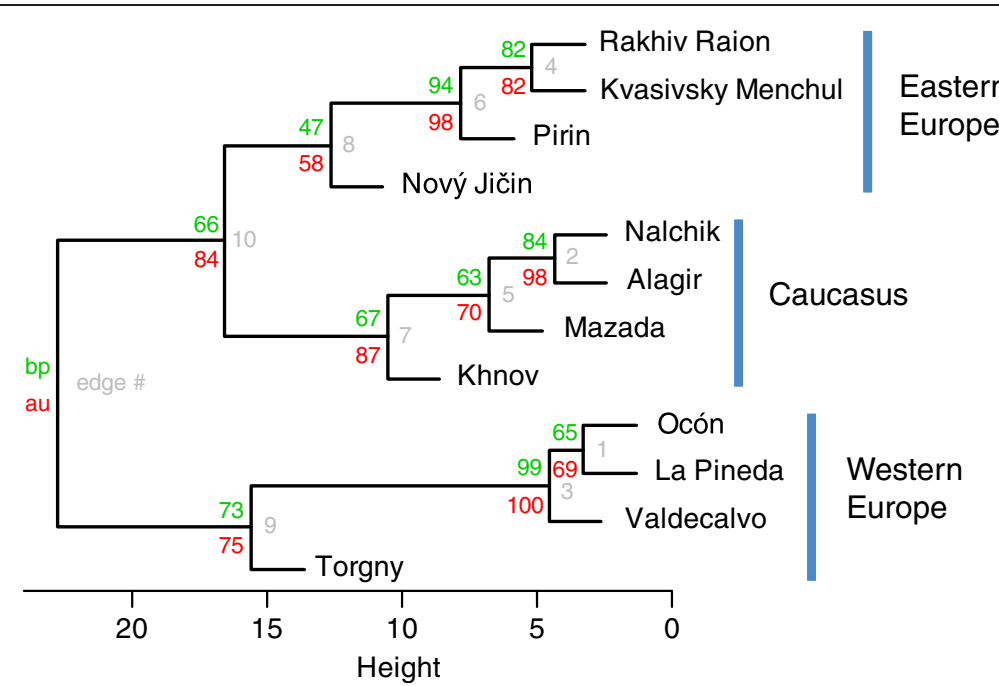

Figure 8 Results of cluster analysis. Au (numbers below), approximately unbiased p-values; bp (numbers above), bootstrap probability p-values; edge \# (numbers right), sequence of cluster construction.

Hirsutiella billabeta Imaz, Galicia, Moraza et Stekolnikov, 2006,

H. zachvatkini (Schluger, 1948),

Xinjiangsha tarda (Schluger, 1957),

Neotrombicula autumnalis (Shaw, 1790),

N. inopinata (Oudemans, 1909),

N. hispanica Kepka, 1960,

N. japonica (Tanaka, Kaiwa, Teramura et Kagaya, 1930),

$N$. jordana Imaz, Galicia, Moraza et Stekolnikov, 2006,

N. vulgaris (Schluger, 1955),

Ericotrombidium hasei (Feider 1958),

Leptotrombidium europaeum (Daniel et Brelich, 1959),

L. silvaticum Hushcha et Schluger, 1967,

Brunehaldia bulgarica Vercammen-Grandjean et Kolebinova, 1966,

Cheladonta ikaoensis (Sasa, Sawada, Kano, Hayashi et Kumada, 1951),

C. pannonica (Kepka 1956),

Helenicula olsufjevi (Schluger, 1955),

Schoutedenichia dipodilli Vercammen-Grandjean, 1958,

S. krampitzi (Willmann, 1955).

To collect chiggers from vegetation is of primary importance in order to find the agent causing human trombiculiasis. Chigger mites located on grass, shrubs or low tree branches are unfed larvae ready to attack their hosts. Chigger infestation in humans is very probable due to direct contact with these substrates during excursions, hiking or working. All human cases of trombiculiasis recorded in La Rioja have been diagnosed in people that had been in contact with the vegetation from Sierra Cebollera Natural Park during the season when the peak of abundance of $N$. autumnalis and related species is usually recorded in Europe $[6,14,43]$. Affected people do not detect the presence of trombiculid mites. In fact, chigger bites are noticed later on, due to the associated intense itching. By then, the mites are detached and examination of the patients skin does not reveal any "harvest bug". The association between chigger mites and human trombiculiasis in the study area is only based on epidemiological evidence. In accordance with this, collections of chiggers from vegetation have been made previously in Spain $[21,44]$. All collected chiggers have been identified as $N$. autumnalis but with insufficient taxonomic evidence. Since $N$. autumnalis is closely related to $N$. inopinata, the characteristics that distinguish these species should be examined in each case in order to confirm the identification. Neotrombicula inopinata clearly differs from $N$. autumnalis by the presence of eight or more setae in 1st and 2nd rows of dorsal idiosomal setae (Figures 5 and 6), rarely six or seven setae in one of these rows, while $N$. autumnalis always has six setae in both rows. Accordingly, the number of dorsal idiosomal setae is 36-45 in N. inopinata and 26-33 in $N$. autumnalis. Futhermore, $N$. inopinata is slightly larger than $N$. autumnalis (larger scutum, longer setae, and longer legs), but intervals for individual morphometric traits overlapped when our entire sample was compared to specimens of $N$. autumnalis collected throughout its geographic range [38].

It should be noted that taxonomical basis of many studies concerning trombiculiasis is inadequate or nonexistent. A notable case was the record of $N$. autumnalis on a little bittern from Turkey [45], where no taxonomic evidence was provided. In fact, the existence of this species in Turkey is not confirmed [17]. Occasionally, when authors try to support their identifications by morphological data, these are surprisingly inappropriate. For example, Guarneri 
et al. [46] provided some descriptions in order to justify their record of $N$. autumnalis in Italy. Their method included traits common to larvae of several mite families, such as three pairs of legs with three claws, paired eyes, hooked chelicerae, segmented palps, and some of the typical traits shared by many chigger mite genera such as pentagonal scutum with five setae and two sensilla, nude galeal seta, and tricuspid palpal claw. Kampen [9] treated N. inopinata and N. vernalis as "subspecies or ecotypes" of $N$. autumnalis following old papers of Kepka $[13,47]$, ignoring all subsequent development of chigger mite taxonomy. Schöler et al. [10] stated that the only species involved in their investigation is $N$. autumnalis. Nevertheless, only outdated references [13] and no information about the identification process are included. In the light of these facts, most published data concerning $N$. autumnalis as the causal agent of trombiculiasis should be considered as doubtful. A confirmation of the role of this species in human trombiculiasis, based on new collections and appropriate examination, is required.

In Spain, human trombiculiasis has been only described in the study area [21], and no cases have been reported from the remainder of the country. According to our data, $N$. inopinata is the only chigger species on vegetation during the seasonal outbreak of trombiculiasis. Therefore, it is the only candidate for the causative agent of trombiculiasis in this territory. However, we cannot conclude that $N$. inopinata is the only mite of medical and veterinary importance in northern Spain. To date, no other trombiculid species has been found in $\mathrm{La}$ Rioja, although additional chigger collections from birds and small mammals may increase the trombiculid fauna of the region, especially with the species previously recorded in Navarra [20]. Thus, it is highly probable that $N$. autumnalis parasitizes small mammals in the study area, although its role as causative agent of trombiculiasis is unclear. The different height of locations where unfed chiggers wait for their hosts (e.g. vegetation, low tree branches or forest floor), could result in the different host spectra of diverse trombiculid species [39,48]. According to our results, since $N$. autumnalis has not been collected from vegetation, it would be unlikely to attack humans or large animals, whereas $N$. inopinata would have a privileged position to infest humans. The identification of engorged trombiculid mites that have developed their stylostomes, directly removed from humans or domestic animals is essential to define the etiological agent of trombiculiasis.

\section{Conclusion}

Neotrombicula inopinata is the most likely causative agent of trombiculiasis in northern Spain, rather than $N$. autumnalis, the species usually regarded as the main human-attacking chigger mite in Europe. Taking into consideration that $N$. inopinata is widely distributed in
Europe, this species could be hidden behind the common name of "the European harvest bug" together with $N$. autumnalis, or even exceed the latter in medical and veterinary importance.

\section{Competing interests}

The authors declare they have no competing interests.

\section{Authors' contributions}

Collected material, made photographs of the collection site and chigger clusters: PS, AMP, JAO. Prepared and identified material, made measurements and microphotographs, performed statistical evaluation, analyzed the data: AAS. Wrote the paper: AAS, PS, AMP, JAO. All authors read and approved the final version of the manuscript.

\section{Acknowledgements}

We are grateful to David Mazuelas (Abies Environment Resources Inc.), Óscar Gutiérrez (Aranzadi Sciences Society), Naina I Kudryashova (ZMMU), Andrey B Shatrov (ZIN), and Ivan Literák (University of veterinary and pharmaceutical sciences, Brno, Czech Republic) who provided us with materials. We wish to express our appreciation to Dr Lesley Bell-Sakyi (The Pirbright Institute, UK) for reviewing the English language of this manuscript. We also thank two anonymous reviewers for useful comments. This research was supported by a grant from the Russian Foundation for Basic Research No. 12-04-00354-a (AAS) and by a grant from the Government of La Rioja (FOMENTA 2007/14) (PS, AMP, JAO).

\section{Author details}

${ }^{1}$ Zoological Institute, Russian Academy of Sciences, Universitetskaya Embankment 1, St. Petersburg 199034, Russia. ${ }^{2}$ Center of Rickettsioses and Arthropod-borne Diseases at the Infectious Diseases Department, Hospital San Pedro-Center for Biomedical Research of La Rioja, Logroño, Spain.

Received: 13 November 2013 Accepted: 25 February 2014 Published: 3 March 2014

\section{References}

1. Ripka G, Stekolnikov AA: First finding of the chigger mite Blankaartia acuscutellaris (Acari Trombiculidae) on a human host in Europe. Belg $J$ Entomol 2006, 8:147-151.

2. Winkler A: Neue Ergebnisse in der Trombidioseforschung. I. Mitteilung. Hautarzt 1953, 4:135-138.

3. Methlagl A: Über die Trombidiose in den Österreichischen Alpenländern. Denkschr Österr Akad Wiss Math-Naturwiss KI 1928, 101:213-250.

4. Shatrov $A B$, Stekolnikov AA: Redescription of a human-infesting European trombiculid mite Kepkatrombicula desaleri (Acari: Trombiculidae) with data on its mouthparts and stylostome. Int J Acarol 2011, 37(Suppl 1):176-193.

5. Poulsen PA: Studies on Trombicula autumnalis Shaw and trombidiosis in Denmark. Aarhus: Universitetsforlaget i Aarhus; 1957.

6. Kepka O: Die Trombiculinae (Acari, Trombiculidae) in Österreich. Zeitschr Parasitenk 1964, 23:548-642.

7. Daniel M: Trombiculosis - a serious problem of urbanized areas. Meditsinskaya Parazitol Parazit Bolezni 1983, 5:52-57 [In Russian].

8. Daniel M, Rosický B: Rozšíření trombikulózy v Praze a přilehlých rekreacních oblastech [Dissemination of trombiculiasis in Prague and the surrounding recreational areas]. Českosl Epidemiol Mikrobiol Imunol 1985, 34:144-148.

9. Kampen H: Die Herbstmilbe Neotrombicula autumnalis und andere parasitische Laufmilben (Acari, Trombiculidae) als Verursacher von Hauterkrankungen in Mitteleuropa. In Denisia 0006: diverse (2002): Amöben, Bandwürmer, Zecken... Parasiten und parasitäre Erkrankungen des Menschen in Mitteleuropa. Edited by Aspöck H. Linz: Oberösterreichisches Landesmuseum, Biologiezentrum; 2002:461-476. http://www. landesmuseum.at/pdf_frei_remote/DENISIA_0006_0461-0476.pdf.

10. Schöler A, Maier WA, Kampen H: Multiple environmental factor analysis in habitats of the harvest mite Neotrombicula autumnalis (Acari: Trombiculidae) suggests extraordinarily high euryoecious biology. Exp Appl Acarol 2006, 39:41-62. 
11. Hirst S: On the "Harvest bug" (Microtrombidium Autumnalis, Shaw). J Econ Biol 1915, 10:73-77.

12. Richards WS: The variation of the British harvest mite (Trombiculidae, Acarina). Parasitology 1950, 40:105-117.

13. Kepka O: Zur Taxonomie der Formen von Neotrombicula autumnalis (Shaw, 1790) (Acari, Trombiculidae). Zeitschr Zool Syst Evol 1964, 2:123-173.

14. Kolebinova MG: Acariformes, Trombidioidea, Trombiculidae, Leeuwenhoekiidae. Sofia: Aedibus Academie Scientiarium Bulgaricae; 1992 [In Bulgarian].

15. Kudryashova Nl: Chigger mites (Acariformes, Trombiculidae) of East Palaearctics. Moscow: KMK Scientific Press; 1998 [In Russian].

16. Stekolnikov AA: A revision of the chigger mite species group vulgaris (Trombiculidae: Neotrombicula). Parazitologiya 1999, 33:387-403 [In Russian].

17. Stekolnikov AA, Daniel M: Chigger mites (Acari: Trombiculidae) of Turkey. Zootaxa 2012, 3216:1-104

18. Kepka O: Die Trombiculidae (Acari) der Iberischen Halbinsel. II. Mitteilung. Zeitschr Parasitenk 1960, 20:191-206.

19. Pereira-Lorenzo A: Chiggers (Acarina: Trombiculidae) parasitizing small mammals in Galicia (NW Spain). Acarologia 1993, 34:323-329.

20. Imaz A, Galicia D, Moraza ML, Stekolnikov AA: Contribution to the knowledge of chigger mites (Acari: Trombiculidae) parasitizing Apodemus sylvaticus (L.) (Rodentia, Muridae) on the Iberian Peninsula. Acarologia 2006, 46:53-64.

21. Jiménez S, Gastón I, Pérez A, Oteo JA: A seasonal outbreak of human parasitation by chiggers in La Rioja (Northern Spain). Clin Microbiol Infect 2001, 7(s1):348.

22. Oteo JA, Portillo A, Santibáñez S, Blanco JR, Pérez-Martínez L, Ibarra V: Cluster of cases of human Rickettsia felis infection from Southern Europe (Spain) diagnosed by PCR. J Clin Microbiol 2006, 44:2669-2671.

23. Literak I, Stekolnikov AA, Sychra O, Dubska L, Taragelova V: Larvae of chigger mites Neotrombicula spp. (Acari: Trombiculidae) exhibited Borrelia but no Anaplasma infections: a field study including birds from the Czech Carpathians as hosts of chiggers. Exp Appl Acarol 2008, 44:307-314

24. Schluger EG, Vysotzkaja SO: On the fauna of chigger mites (Acariformes, Trombiculidae) from the Transcarpathian Region. Parazitologiya 1970, 4:153-165 [In Russian].

25. Sosnina EF, Visockaja SO, Markov GN, Hristov L: Beitrag zur Arthropodenfauna auf Kleinsäuger in Bulgarien. Zool Anz 1969, 183:370-378.

26. Stekolnikov AA: Leptotrombidium (Acari: Trombiculidae) of the world. Zootaxa 2013, 3728:1-173.

27. Suzuki R, Shimodaira H: Package 'pvclust'. Hierarchical clustering with p-values via multiscale bootstrap resampling. Ver 1.2-2. 2011. http://cran. r-project.org/web/packages/pvclust/index.html.

28. $\mathrm{R}$ Core Team: $R$ : A language and environment for statistical computing. Vienna: $\mathrm{R}$ Foundation for Statistical Computing; 2013. http://www.r-project.org.

29. Shimodaira $H$ : An approximately unbiased test of phylogenetic tree selection. Syst Biol 2002, 51:492-508.

30. Shimodaira H: Geometry of multiscale bootstrap resampling. In 2nd International symposium on information geometry and its applications: December 12-16, 2005, Tokyo; 2005. http://www.stat.t.u-tokyo.ac.jp/ infogeo/ abst/HidetoshiSHIMODAIRA.pdf.

31. Suzuki R, Shimodaira H: Pvclust: an R package for hierarchical clustering with p-values. 2006. http://www.is.titech.ac.jp/ shimo/prog/pvclust/.

32. Solomon L: Contribution à la connaissance de l'acaroparasitofaune des petits mamifères de Dobroudja. Travaux Mus Hist Nat G Antipa 1968, 8:671-692.

33. Haitlinger R: Acarina of small mammals in Hungary. Polskie Pismo Entomol 1979, 49:553-566.

34. Kováčik J: Roztoče čel'ade Trombiculidae (Acarina) drobných zemných cicavcov Vihorlatu. Zborn Východoslov Múz Košiciach, Prír Vedy 1983, 23:183-189.

35. Daniel M, Pejcoch M, Kaluz S: Acarina: Prostigmata (Trombiculidae). Folia Fac Scient Nat Univ Masarykianae Brunensis, Biol 1995, 92:71-74.

36. Mąkol J, Cichocki J, Felska M, Kłosińska A, Łaydanowicz J, Łupicki D, Gabryś G: A new data on biology and taxonomy of Neotrombicula inopinata (Oudemans, 1909) and Leptotrombidium russicum (Oudemans, 1902) (Acari: Actinotrichida: Trombiculidae). Ann Zool 2010, 60:419-427.

37. Vercammen-Grandjean PH: The chigger mites of the Far East (Acarina: Trombiculidae and Leeuwenhoekiidae). Washington, DC: US Army Medical Research and Development Command; 1968.
38. Stekolnikov AA: New data on fauna and systematics of chiggers of the autumnalis group (Trombiculidae: Neotrombicula). Parazitologiya 1997, 31:527-542 [In Russian].

39. Stekolnikov AA: Variability of chigger mites of the talmiensis group, genus Neotrombicula Hirst, 1925 (Acari, Trombiculidae) in the areas of sympatry in the Western Caucasus. Entomol Obozr 2002, 81:761-777 [In Russian].

40. Stekolnikov AA, Klimov PB: A revision of chiggers of the minuta species-group (Acari: Trombiculidae: Neotrombicula Hirst, 1925) using multivariate morphometrics. Syst Parasitol 2010, 77:55-69.

41. Kepka O: Die Trombiculidae (Acari) der Iberischen Halbinsel. I. Mitteilung. Zeitschr Parasitenk 1960, 19:548-552.

42. Varma MGR: Mites (family Trombiculidae) parasitizing birds migrating from Africa to Europe. Bull World Health Org 1964, 31:411-416.

43. Elton C, Keay G: The seasonal occurrence of harvest mites Trombicula autumnalis Shaw on voles and mice near Oxford. Parasitology 1936, 28:110-114.

44. Fernández-Soto P, Pérez-Sánchez R, Encinas-Grandes A: Molecular detection of Ehrlichia phagocytophila genogroup organisms in larvae of Neotrombicula autumnalis (Acari: Trombiculidae) captured in Spain. J Parasitol 2001, 87:1482-1483.

45. Cakiroglu D, Pekmezci D, Meral Y, Gokalp G, Acici M: Trombiculidae larvae (Neotrombicula autumnalis) infestation in a Little Bittern (Ixobrychus minutus) in Turkey. Parasitol Res 2008, 102:1077-1079.

46. Guarneri F, Pugliese A, Giudice E, Guarneri C, Giannetto S, Guarneri B: Trombiculiasis: clinical contribution. Eur J Dermatol 2005, 15:495-496.

47. Kepka O: Die Herbstmilbe (Neotrombicula autumnalis). Angew Parasitol 1965, 6(Suppl 12):1-13.

48. Stekolnikov AA, Literák I, Čapek M, Havlíček M: Chigger mites (Acari: Trombiculidae) from wild birds in Costa Rica, with a description of three new species. Folia Parasitol 2007, 54:59-67.

doi:10.1186/1756-3305-7-90

Cite this article as: Stekolnikov et al: Neotrombicula inopinata (Acari: Trombiculidae) - a possible causative agent of trombiculiasis in Europe. Parasites \& Vectors 2014 7:90.

\section{Submit your next manuscript to BioMed Central and take full advantage of:}

- Convenient online submission

- Thorough peer review

- No space constraints or color figure charges

- Immediate publication on acceptance

- Inclusion in PubMed, CAS, Scopus and Google Scholar

- Research which is freely available for redistribution

Submit your manuscript at www.biomedcentral.com/submit
C) Biomed Central 